Brit. F. vener. Dis. (1973) 49, 542

\title{
Social aspects of venereal disease I. Sociological determinants of venereal disease
}

\author{
GAVIN HART \\ First Australian Field Hospital, Vung Tau, South Vietnam
}

In recent years there has been an increasing interest in the psychological and sociological aspects of venereal disease. Unfortunately, the significance of some reported data is uncertain, through lack of suitable controls, bias in sampling, or other reasons. This confusion has been aggravated by the tendency to generalize about venereal disease patients by building a composite picture from participants in widely differing environments. In particular, it might be anticipated that the type of patient encountered in a war environment, with its associated stresses and absence of inhibiting influences, may bear little resemblance to that seen in a stable civilian community.

Sociological accounts of allied servicemen have been rare since those reporting studies pertaining to the second world war (e.g. Ahrenfeldt, 1958; Sutherland, 1950; Wittkower and Cowan, 1944; Wittkower, 1948; Watts and Wilson, 1945; Brody, 1948; Ratcliffe, 1947).

These studies provide fairly consistent facets of the military patients studied:

(1) There tends to be a higher incidence of venereal disease in low intelligence groups and those with less education.

(2) 85 to 90 per cent. of patients had been infected for the first time and 10 to 15 per cent. had multiple infections. There has not been universal agreement on the relationship of personality to venereal infection. While increased incidence has been noted in neurotics or the emotionally immature, other studies have not found this relationship. It has been suggested, however, that, while any soldier may contract venereal disease once, multiple infection is indicative of a weak personality-'A good soldier may get VD. However, if a man gets VD twice, or more often, it indicates a weak personality because he does not learn by experience. Such patients should be thoroughly investigated.' (Watts and Wilson, 1945)

(3) There is a greater incidence of both army and civilian crime among venereal disease patients.

Received for publication February 21, 1973

Present address: Box 32, Edithburgh, South Australia 5583
(4) Although there tends to be a higher incidence among single soldiers, this is not a marked feature.

(5) High alcohol intake is associated with venereal disease.

(6) A disproportionate number of patients have visited prostitutes in civilian life and experienced intercourse at a younger age than the rest of the population.

It might be expected that these characteristics elicited 30 years ago may not be applicable in modern times. Thus, the almost revolutionary changes in sexual standards during recent decades, altered patterns of warfare, and a different geographical location may produce quite different behaviour and sequelae from those encountered in Europe during the second world war. The present study describes the type of patient encountered among Australian troops during the Vietnam conflict.

\section{Methods}

Over a 4-month period 488 venereal disease clinic attenders of sergeant's rank or below were requested to complete a sociological questionnaire and an accompanying Eysenck personality inventory Form A (Eysenck and Eysenck, 1964); 27 (5.5 per cent.) declined and seventeen (3.5 per cent.) forms were discarded because of unsatisfactory completion. Thus $\mathbf{4 4 4}$ questionnaires remained for analysis.

The series analysed and the series of defaulters (soldiers declining plus those not completing the questionnaire satisfactorily) did not differ significantly with respect to type of enlistment and rank frequencies $(P>0 \cdot 20)$. Those excluded for inconsistencies did not differ significantly from the series analysed with respect to education and marital state $(P>0.20)$. It, therefore, seems reasonable to assume that the absence of other data from the defaulters did not markedly affect the results obtained.

A control series of 230, randomly sampled from 1,200 soldiers of similar rank in the area under study, completed a personality inventory and a modified questionnaire. There were four ( 2 per cent.) inadequately completed forms and twenty ( 9 per cent.) were discarded because the L Score was greater than 5, leaving 206 (89 per cent.) inventories and questionnaires for analysis. 
Parental occupation was converted to socioeconomic status by utilizing the 7-point classification of Congalton (1969).

The significance of differences between groups was assessed by $\chi^{2}$ calculations.

The study samples contained both volunteers (regular soldiers) and conscripts (national servicemen). The army selected conscripts randomly (by date of birth) so that the conscript controls give some point of reference to the average Australian male of this age group (20 to 22 years). The randomization is disturbed by fall-out due to medical unfitness or administrative exemption, selection of a limited number for officer training, and the uneven distribution of characteristics leading to service in Vietnam. The volunteers, by contrast, represent a selected occupational group.

\section{Results}

(1) INTERCOURSE IN VIETNAM

134 (65 per cent.) of the control group had intercourse in Vietnam. Table I outlines the factors associated with an increased incidence of intercourse.

(i) Terms of enlistment and marital status

Overall, intercourse was experienced by more volunteers (72.5 per cent.) than conscripts (58.5 per cent.) and by more single soldiers ( 71 per cent.) than married ones (50 per cent.). Single volunteers had the highest rate ( 86 per cent.) and conscripted married members the lowest ( $44 \cdot 5$ per cent.), with the single conscripts (61 per cent.) and married volunteers (52.5 per cent.) forming an intermediate group.

\section{(ii) Age}

Maximum incidence ( 87 per cent.) occurred in the under 21 group and the lowest incidence (56 per cent.) among those over 30 years old.

\section{(iii) Alcohol intake in homeland}

The highest incidence occurred among very heavy drinkers (intoxicated more than once a fortnight) (88.5 per cent.) and the lowest among social drinkers (47.5 per cent.).

\section{(iv) Education}

This was one of the more important factors, the incidence among those with higher education (29.5 per cent.) being less than half that among those with limited secondary education (74 per cent.).

TABLE I Factors associated with an increased incidence of intercourse with prostitutes in Vietnam

\begin{tabular}{|c|c|c|c|c|c|}
\hline \multirow{2}{*}{ Parameter } & & \multirow{2}{*}{ Total } & \multicolumn{2}{|c|}{ Intercourse } & \multirow{2}{*}{$P$} \\
\hline & & & No. & Per cent. & \\
\hline Age (yrs) & $\begin{array}{l}\text { Under } 21 \\
21-25 \\
26-30 \\
\text { Over } 30\end{array}$ & $\begin{array}{r}30 \\
151 \\
9 \\
16\end{array}$ & $\begin{array}{r}26 \\
93 \\
6 \\
9\end{array}$ & $\begin{array}{l}87 \\
61 \cdot 5 \\
66 \cdot 5 \\
56\end{array}$ & $<0 \cdot 10$ \\
\hline $\begin{array}{l}\text { Marital status and } \\
\text { terms of enlistment }\end{array}$ & $\begin{array}{l}\text { Single conscript } \\
\text { Married conscript } \\
\text { Single volunteer } \\
\text { Married volunteer }\end{array}$ & $\begin{array}{l}90 \\
18 \\
58 \\
40\end{array}$ & $\begin{array}{r}55 \\
8 \\
50 \\
21\end{array}$ & $\begin{array}{l}61 \\
44 \cdot 5 \\
86 \\
52 \cdot 5\end{array}$ & $<0.01$ \\
\hline Alcohol intake & $\begin{array}{l}\text { Nil } \\
\text { Social } \\
\text { Regular } \\
\text { Heavy (intoxicated } \\
\text { Very heavy }\end{array}$ & $\begin{array}{r}5 \\
80 \\
76 \\
\\
19 \\
26\end{array}$ & $\begin{array}{r}3 \\
38 \\
55 \\
\\
15 \\
23\end{array}$ & $\begin{array}{l}60 \\
47 \cdot 5 \\
72 \cdot 5 \\
79 \\
88 \cdot 5\end{array}$ & $<0.001$ \\
\hline Civil arrests & $\begin{array}{l}\text { Yes } \\
\text { No }\end{array}$ & $\begin{array}{r}49 \\
157\end{array}$ & $\begin{array}{l}42 \\
92\end{array}$ & $\begin{array}{l}86 \\
58 \cdot 5\end{array}$ & $<0.01$ \\
\hline Army charges & $\begin{array}{l}\text { Nil } \\
1 \\
2-5 \\
\text { More than } 5\end{array}$ & $\begin{array}{r}105 \\
57 \\
35 \\
9\end{array}$ & $\begin{array}{r}64 \\
35 \\
26 \\
9\end{array}$ & $\begin{array}{l}61 \\
61 \cdot 5 \\
74 \cdot 5 \\
100\end{array}$ & $<0 \cdot 10$ \\
\hline Family size & $\begin{array}{l}\text { Only child } \\
2 \text { children } \\
3 \text { children } \\
4 \text { children } \\
5 \text { children } \\
\text { More than } 5\end{array}$ & $\begin{array}{r}4 \\
40 \\
59 \\
50 \\
17 \\
36\end{array}$ & $\begin{array}{r}2 \\
22 \\
31 \\
40 \\
12 \\
27\end{array}$ & $\begin{array}{l}50 \\
55 \\
52 \cdot 5 \\
80 \\
70 \cdot 5 \\
75\end{array}$ & $<0.05$ \\
\hline
\end{tabular}


(v) Civil arrests and army charges

Those with previous civil arrests had a higher incidence ( 86 per cent.) than others (58.5 per cent.), but the relationship with army charges was much less significant, although the incidence was higher (82 per cent.) for those charged more than once.

(vi) Family size

The highest incidence occurred among those soldiers with three siblings ( 80 per cent.) and those with more than four siblings ( 75 per cent.). An associated high incidence (86 per cent.) occurred in those whose family order was lower than fifth, but otherwise there was no relationship to birth order.

(vii) Personality

Those having intercourse were more extroverted and neurotic than the abstainers (Hart, 1973). (viii) Parameters not associated with an increased incidence of intercourse included rank, time in Vietnam, racial origin, stability of parental family, church attendance in Vietnam, depth of religious conviction, and social status of parents.

(2) VENEREAL DISEASE

The questionnaires from clinic patients were divided into those who had acquired venereal disease (VD) and those who had not (no-VD). These results were compared with those for the control series divided into those having intercourse (ic) and abstainers (no-ic). In many characteristics there is a consistent trend along the sequence: no-ic, ic, no-VD, and VD, with abstainers and VD sufferers at the extremes, whereas the two groups, ic and no-VD, are very similar and occupy an intermediate position. Despite

TABLE II Sociological characteristics associated with venereal disease

\begin{tabular}{|c|c|c|c|c|c|c|c|}
\hline \multirow{2}{*}{ Parameter } & & \multicolumn{2}{|c|}{ Control } & \multicolumn{2}{|c|}{ No $V D$} & \multicolumn{2}{|l|}{$V D$} \\
\hline & & No. & Per cent. & No. & Per cent. & No. & Per cent. \\
\hline $\begin{array}{l}\text { Terms of } \\
\text { enlistment }\end{array}$ & $\begin{array}{l}\text { Conscript } \\
\text { Volunteer }\end{array}$ & $\begin{array}{r}108 \\
98\end{array}$ & $\begin{array}{l}52 \\
48\end{array}$ & $\begin{array}{l}105 \\
108\end{array}$ & $\begin{array}{l}49 \\
51\end{array}$ & $\begin{array}{r}86 \\
145\end{array}$ & $\begin{array}{l}37 \\
63\end{array}$ \\
\hline Age (yrs) & $\begin{array}{l}\text { Under } 21 \\
21-25 \\
26-30 \\
\text { Over } 30\end{array}$ & $\begin{array}{r}30 \\
151 \\
9 \\
16\end{array}$ & $\begin{array}{r}14 \cdot 5 \\
73 \cdot 5 \\
4 \cdot 5 \\
7 \cdot 5\end{array}$ & $\begin{array}{r}27 \\
164 \\
12 \\
10\end{array}$ & $\begin{array}{l}12 \cdot 5 \\
77 \\
5 \cdot 5 \\
5\end{array}$ & $\begin{array}{r}58 \\
155 \\
11 \\
7\end{array}$ & $\begin{array}{r}25 \\
67 \\
5 \\
3\end{array}$ \\
\hline $\begin{array}{l}\text { Marital } \\
\text { status }\end{array}$ & $\begin{array}{l}\text { Single } \\
\text { Single, steady girl } \\
\text { Single, fiancée } \\
\text { Happily married } \\
\text { Others }\end{array}$ & $\begin{array}{r}77 \\
33 \\
38 \\
55 \\
3\end{array}$ & $\begin{array}{l}37 \cdot 5 \\
16 \\
18 \cdot 5 \\
26 \cdot 5 \\
1 \cdot 5\end{array}$ & $\begin{array}{r}82 \\
41 \\
32 \\
53 \\
5\end{array}$ & $\begin{array}{l}38 \cdot 5 \\
19 \\
15 \\
25 \\
2 \cdot 5\end{array}$ & $\begin{array}{r}123 \\
29 \\
29 \\
47 \\
3\end{array}$ & $\begin{array}{l}53 \\
12 \cdot 5 \\
12 \cdot 5 \\
20 \cdot 5 \\
1 \cdot 5\end{array}$ \\
\hline $\begin{array}{l}\text { Army } \\
\text { charges }\end{array}$ & $\begin{array}{l}\text { Nil } \\
\text { One } \\
2-5 \\
6-10 \\
\text { Over } 10\end{array}$ & $\begin{array}{r}105 \\
57 \\
35 \\
6 \\
3\end{array}$ & $\begin{array}{l}51 \\
27 \cdot 5 \\
17 \\
3 \\
1 \cdot 5\end{array}$ & $\begin{array}{r}99 \\
51 \\
50 \\
7 \\
6\end{array}$ & $\begin{array}{l}46 \cdot 5 \\
24 \\
23 \cdot 5 \\
3 \cdot 5 \\
2 \cdot 5\end{array}$ & $\begin{array}{r}65 \\
68 \\
73 \\
16 \\
9\end{array}$ & $\begin{array}{l}28 \\
29 \cdot 5 \\
31 \cdot 5 \\
7 \\
4\end{array}$ \\
\hline $\begin{array}{l}\text { Time in } \\
\text { Vietnam } \\
\text { (mths) }\end{array}$ & $\begin{array}{l}\text { Under } 3 \\
3-6 \\
\text { Over } 6\end{array}$ & $\begin{array}{r}41 \\
65 \\
100\end{array}$ & $\begin{array}{l}20 \\
31 \cdot 5 \\
48 \cdot 5\end{array}$ & $\begin{array}{r}30 \\
68 \\
115\end{array}$ & $\begin{array}{l}14 \\
32 \\
54\end{array}$ & $\begin{array}{r}29 \\
62 \\
140\end{array}$ & $\begin{array}{l}12 \cdot 5 \\
27 \\
60 \cdot 5\end{array}$ \\
\hline $\begin{array}{l}\text { Religious } \\
\text { beliefs }\end{array}$ & $\begin{array}{l}\text { Serious } \\
\text { Not serious }\end{array}$ & $\begin{array}{r}56 \\
150\end{array}$ & $\begin{array}{l}27 \\
73\end{array}$ & $\begin{array}{r}41 \\
172\end{array}$ & $\begin{array}{l}19 \\
81\end{array}$ & $\begin{array}{r}36 \\
195\end{array}$ & $\begin{array}{l}15 \cdot 5 \\
84 \cdot 5\end{array}$ \\
\hline Rank & $\begin{array}{l}\text { Private } \\
\text { NCO }\end{array}$ & $\begin{array}{r}131 \\
75 \\
\end{array}$ & $\begin{array}{l}64 \\
36\end{array}$ & $\begin{array}{r}144 \\
69\end{array}$ & $\begin{array}{l}68 \\
32\end{array}$ & $\begin{array}{r}160 \\
71\end{array}$ & $\begin{array}{l}69 \\
31\end{array}$ \\
\hline $\begin{array}{l}\text { Alcohol } \\
\text { intake }\end{array}$ & $\begin{array}{l}\text { Nil } \\
\text { Social } \\
\text { Regular } \\
\text { Heavy } \\
\text { Very heavy }\end{array}$ & $\begin{array}{r}5 \\
80 \\
76 \\
19 \\
26\end{array}$ & $\begin{array}{c}2 \cdot 5 \\
39 \\
37 \\
9 \\
12 \cdot 5\end{array}$ & $\begin{array}{r}9 \\
90 \\
80 \\
15 \\
19\end{array}$ & $\begin{array}{r}4 \cdot 5 \\
42 \cdot 5 \\
37 \cdot 5 \\
7 \\
8 \cdot 5\end{array}$ & $\begin{array}{r}3 \\
80 \\
104 \\
24 \\
20\end{array}$ & $\begin{array}{c}1 \cdot 5 \\
34 \cdot 5 \\
45 \\
10 \cdot 5 \\
8 \cdot 5\end{array}$ \\
\hline Education & $\begin{array}{ll}\text { Primary } & \\
\text { Secondary } & 1-3 \text { yrs } \\
\text { Higher } & 4-6 \text { yrs }\end{array}$ & $\begin{array}{r}3 \\
108 \\
78 \\
17\end{array}$ & $\begin{array}{r}1 \cdot 5 \\
52 \cdot 5 \\
37 \cdot 5 \\
8 \cdot 5\end{array}$ & $\begin{array}{r}13 \\
118 \\
74 \\
8\end{array}$ & $\begin{array}{c}6 \\
55 \cdot 5 \\
34 \cdot 5 \\
4\end{array}$ & $\begin{array}{r}5 \\
153 \\
61 \\
12\end{array}$ & $\begin{array}{l}2 \\
66 \\
26 \cdot 5 \\
5 \cdot 5\end{array}$ \\
\hline Family size & $\begin{array}{l}\text { Only child } \\
\text { Two children } \\
\text { Three children } \\
\text { Four children } \\
\text { Five children } \\
\text { Over five }\end{array}$ & $\begin{array}{r}4 \\
40 \\
59 \\
50 \\
17 \\
36\end{array}$ & $\begin{array}{c}2 \\
19 \cdot 5 \\
28 \cdot 5 \\
24 \\
8 \cdot 5 \\
17 \cdot 5\end{array}$ & $\begin{array}{r}8 \\
40 \\
40 \\
45 \\
28 \\
52\end{array}$ & $\begin{array}{r}4 \\
19 \\
19 \\
21 \\
13 \\
24\end{array}$ & $\begin{array}{l}10 \\
47 \\
40 \\
51 \\
28 \\
55\end{array}$ & $\begin{array}{l}4 \cdot 5 \\
20 \cdot 5 \\
17 \\
22 \\
12 \\
24\end{array}$ \\
\hline
\end{tabular}


this consistent trend, differences between the control and study group are relatively slight. The parameters related to venereal disease are summarized in Table II.

\section{(i) Terms of enlistment}

Venereal disease was significantly less common among conscripts. Thus, although conscripts contributed 52 per cent. of the control series their contributions to the no-VD, and VD groups were 49 per cent. and 37 per cent. respectively $(P<0.01)$.

\section{(ii) Age}

This was a significant factor in that those under 21 contributed 25 per cent. to the VD group compared with 14.5 per cent. of the control group. Soldiers over 30 years of age contributed only 3 per cent. of VD sufferers compared to 7.5 per cent. of controls (comparing no-ic to VD for these age groups; $\mathrm{P}<0.001)$.

\section{(iii) Marital status}

Actual marriage proved a significant deterrent, but the influence of a girl friend or fiancée was not significant. The VD group contained 53 per cent. single unattached soldiers compared to 20.5 per cent. married soldiers, whereas the corresponding contributions to the control series were 37.5 and 26.5 per cent. respectively (married $v$. single unattached; $P<0.01$ ).

\section{(iv) Number of charges in the army}

This factor proved very significant in that those who had never been charged provided 28 per cent. of VD sufferers compared with 51 per cent. of the control group, whereas those with multiple charges provided 42.5 per cent. of VD sufferers and only 21.5 per cent. of controls $(P<0.001)$.

\section{(v) Time in Vietnam}

Length of service in Vietnam had a mild effect on the likelihood of contracting VD. Thus 12.5 per cent. of those infected had been in Vietnam less than 3 months (20 per cent. of controls) and 60.5 per cent. had been in Vietnam for more than 6 months $(48.5$ per cent. of controls) $(0.02<\mathrm{P}<0.05)$.

This time relationship was probably produced by those who continued to have intercourse regularly throughout their tour.

\section{(vi) Religious beliefs}

Although this relationship was not particularly significant, there was a tendency for those with strong religious beliefs to make smaller contributions to the ic and clinic groups (from 28.5 per cent. in no-ic, 23.5 per cent. in ic, 19 per cent. in no-VD to 15.5 per cent. in VD; $P<0 \cdot 10)$.

\section{(vii) Rank}

Rank was not particularly significant, with private soldiers contributing 69 per cent. of VD patients compared with 64 per cent. of the controls $(P<0 \cdot 10)$.

(viii) Patients with venereal disease were significantly more extroverted and neurotic than the controls (Hart, 1973).

\section{(ix) Alcohol intake}

Among conscripts there was very little correlation between the incidence of venereal disease and alcohol intake. However, among volunteers, the steady drinkers made a large contribution (47 per cent. compared with 30.5 per cent. of controls) whereas the very heavy drinkers made a small contribution ( 6 per cent. compared with 19 per cent. of controls; $\mathrm{P}<0.001)$.

\section{(x) Education}

Almost the whole effect of education on venereal disease infection was contributed by conscripts, among whom 57.5 per cent. of controls and 39.5 per cent. of venereal disease sufferers had more than 3 years secondary education $(P<0.01)$.

(3) THE MULTIPLE VENEREAL DISEASE PATIENT

Of the 52 per cent. of clinic patients who acquired VD in Vietnam, 72.5 per cent. had only one infection, 26 per cent. had from two to five, and 1.5 per cent. had more than five infections. 41 per cent. had been infected with gonorrhoea and 30 per cent. with non-gonococcal urethritis, and 18 per cent. had contracted more than one type of venereal disease.

Apart from length of service in Vietnam (80 per cent. of multiple patients compared with 53 per cent. of those infected once had been in Vietnam more than 6 months), there was no difference in the distribution of sociological parameters for those who had been infected once and those who had had more than one infection.

(4) SOCIOLOGICAL CHARACTERISTICS OF PROFESSIONAL SOLDIERS

Analysis of data from the clinic attenders disclosed further differences between conscripts and volunteers, in addition to those already discussed (Table III, overleaf).

\section{Summary and Conclusions}

(1) Although several statistically significent differences between the control series and VD patients have been demonstrated, these are not of very great epidemiological significance. The key to this situation is the fact that 65 per cent. of the soldiers had intercourse in Vietnam.

Venereal disease was more frequent among 
TABLE III Some differences between conscripts and volunteers

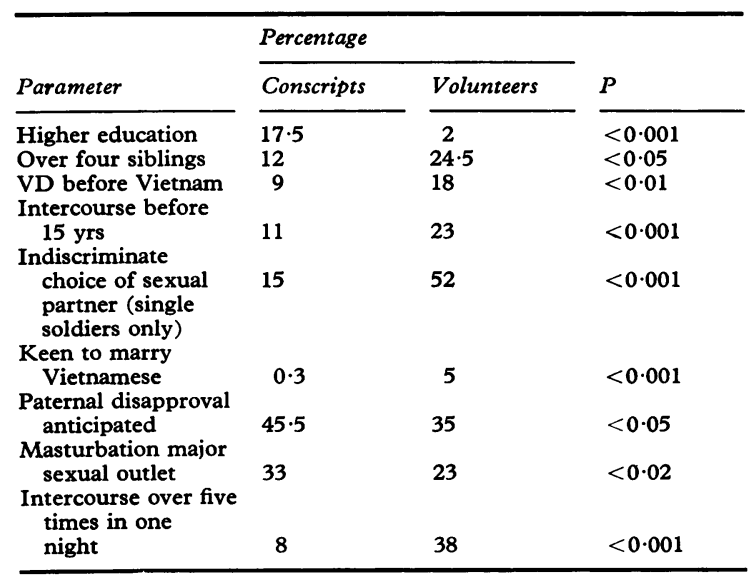

volunteer soldiers, those under 21 , single men, those with less than 3 years secondary education, those with high alcohol intake, and those with frequent army charges. Extroverts and neurotics also contributed disproportionately to the total of venereal disease patients. The most surprising feature was the almost identical findings for those with single infections and those infected more than once.

(2) The venereal disease impact in this situation was not so much a result of the sociological background of those involved, but rather a consequence of the environment. The environmental stresses of a war situation produced behaviour patterns which many participants would not otherwise experience. Thus, this cross-section of venereal disease patients would bear little if any resemblance to that encountered in a stable civilian environment. Sexual behaviour normally encountered in a minority group becomes the experience of the majority of the population.

(3) However, the type of person voluntarily choosing the army as a career tends to possess certain distinctive characteristics which produce behaviour patterns, including those predisposing to venereal infection, quite different from those of the general population. $\mathrm{He}$ is especially prone to venereal disase, not only because of his environmental situation, but because of his characteristic sociological background. He tends to come from a large family, has a limited education, and indulges in intercourse at an early age. Intertwined with these parameters are selective characteristics of ethics and behaviour. Parental disapproval is reduced and marriage vows provide fewer restrictions and inhibitions than in the general community. $\mathrm{He}$ is reluctant to use masturbation as the major sexual outlet and is indiscriminate in his selection of sexual partners (i.e. he epitomizes promiscuity).

Against this background, it is not surprising that he contributes a disproportionate amount to the venereal disease problem in the stable conditions of his home environment. Movement to a war environment produces only a quantitative disturbance of this behaviour and the soldier becomes actively (and emotionally) involved with local prostitutes, has intercourse frequently and in excess, and greatly increases the venereal disease problem.

I am indebted to Lt Col M. A. Naughton, O.B.E., Commanding Officer of the First Australian Field Hospital, for encouragement with this work, and to Major J. Collins, consultant psychiatrist, for continuing assistance with the project.

\section{References}

AHRENFeld , R. H. (1958) 'Psychiatry in the British Army in the Second World War'. Routledge and Kegan Paul, London

BRODY, M. W. (1948) F. vener. Dis. Inform., 29, 334

Congalton, A. A. (1969) 'Status and Prestige in Australia'. Cheshire, Melbourne

EYSENCK, H. J., and EYSENCK, S. B. G. (1964) 'Manual of the Eysenck Personality Inventory'. University of London Press, London

HART, G. (1973) Soc. Sci. Med., 7, 455

Ratcliffe, T. A. (1947) f. roy. Army med. Cps., 89, 122 Sutherland, R. (1950) Brit. F. vener. Dis., 26, 1

Watts, G. O., and WILson, R. A. (1945) Canad. med. Ass. F., 53, 119

WitTKower, E. D. (1948) Brit. F. vener. Dis., 24, 59

- and Cowan, J. (1944) Psychosomat. Med., 6, 287

Aspects sociaux des maladies vénériennes

I. Déterminants sociologiques des maladies vénériennes

SOMMAIRE

(1) Quoique plusieurs différences statistiquement significatives entre des témoins et des malades vénériens aient été démontrées, elles n'ont pas une très grande signification épidémiologique. La clef de cette situation réside dans le fait que 65 pour cent de soldats avaient eu des rapports au Vietnam.

Les maladies vénériennes sont plus fréquentes parmi les soldats volontaires, chez ceux de moins de 21 ans, les célibataires, ceux ayant eu une éducation secondaire inférieure à trois ans, ceux absorbant une forte quantité d'alcool et ceux ayant de fréquentes missions militaires. Les extravertis et les névrosés contribuèrent aussi d'une manière disproportionnée au total des malades vénériens. Le fait le plus surprenant fut que l'on trouva presque la même chose chez les malades n'ayant eu qu'une atteinte et chez ceux qui furent infectés plus d'une fois.

(2) La survenue des maladies vénériennes dans la présente situation ne fut pas tant dépendant du fond sociologique 
des sujets concernés qu'une conséquence de l'environnement. Les circonstances aggressives de l'environnement d'une situation de guerre entraînent des types de comportement que beaucoup de sujets n'auraient pas présenté autrement. Ainsi, cette tranche de vénériens ressemble peu à ce que l'on rencontre dans un environnement civil stable. Normalement, le comportement sexuel d'un groupe réduit recouvre ce que l'on voit dans la majorité de la population.

(3) Quoiqu'il en soit, le type d'individu choisissant volontairement l'armée comme carrière tend à présenter certains caractères distinctifs qui aboutissent à des types de comportement-dont ceux qui prédisposent à l'infection vénérienne-tout-à-fait différents de ceux de la population générale. Il est spécialement prédisposé aux maladies vénériennes, non seulement à cause de son environment, mais à cause de son fond social caractéristique. Il appartient généralement à une famille nombreuse, a une instruction limitée et a recherché les rapports à un âge précoce. Interférant avec ces paramètres, on trouve des caractéristiques sélectives de morale et de comportement. La critique parentielle est réduite et les engagements conjugaux apportent moins de restriction et d'inhibition que dans la communauté générale. Il est peu disposé à employer la masturbation comme exutoire sexuel principal et ne fait pas de discrimination dans le choix de ses partenaires sexuels (c.à.d.: il représente la promiscuité).

Dans ces conditions, il n'est pas surprenant qu'il participe d'une manière disproportionnée au problème vénérien lorsqu'il est dans les conditions stables de son environnement habituel. Le passage à un environnement de guerre apporte seulement un trouble quantitatif à ce comportement et le soldat devient activement (et émotionnellement) en contact avec les prostituées locales; il a les rapports fréquents et en excès, ce qui augmente largement le problème vénérien. 